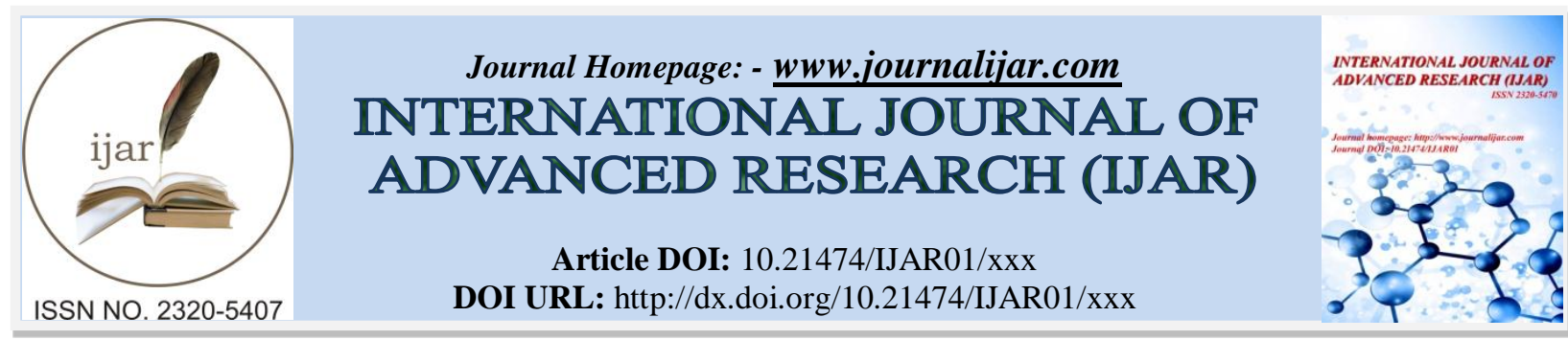

RESEARCH ARTICLE

\title{
THE USE OF ROLE PLAY ACTIVITIES TO IMPROVE ENGLISH SPEAKING SKILL OF THE GRADE 12 STUDENTS OF TECHNOLOGY SCIENCE OF ESCOLA SECUNDÁRIA GERAL 4 DE SETEMBRO UNAMET DILI IN THE SCHOOL YEAR 2017.
}

\section{Norberto Da Costa. Advisors ${ }^{1}$, Dr. Klemens Kolo. Mat ${ }^{2}$ and Santri E. P. Djahimo ${ }^{2}$.}

1. S.Pd. M. App. Ling. Ph.D. Master Program in English Language Education Program.

2. Nusa Cendana University Jln.Panglima Besar Sudirman Kupang, NTT - Indonesia.

\section{Manuscript Info}

Manuscript History

Received: $x x x x x x x x x x x x x x x$

Final Accepted: $x \times x \times x x x x x x x$

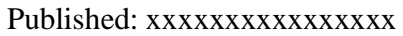

Key words:-

role-play, dialog, speaking skill.

\begin{abstract}
This thesis is entitled, "The use of role play activities to improve speaking skill of grade 12 students of technology science, Escola Secundaria Geral 4 de Setembro UNAMET Dili, in the school year 2017." The aims of this study were to find out whether the role play activities improve studentas' speaking skills. This study employs classroom action- research consisting of two cycles. The treatment of cycle one employed actions: (1) building schemata of dialog context; (2) Preteaching new vocabulary; (3) Drilling difficult sounds and word pronunciation. (4) Performing role play by reciting dialog before the class by pairs of students. (5) Encouraging and motivating students continuously. After the treatment the results show less enthusiasm of students in class participation and the mean score of speaking test is 67.82. Because the result is not satisfactory, the treatment continued to cycle two, with the following innovative actions: (1) Building schemata through extenssion of context. (2) Pre-teaching new vocabulary with examples. (3) Drilling difficult sounds with contrastive analysis technique.(4) Performing role-play through guided substitution towards free speaking. (5) Continuing motivating students through verbal and non-verbal reinforcement. The results show that the students' participation in doing the English class increased dramatically with full enthusiam and this has contributed to the increase of their mean score of speaking test which is 71.63. Although the score is not the best score, the study has been cosidered successful in terms of class participation.
\end{abstract}

Copy Right, IJAR, 2017,. All rights reserved.

\section{Introduction:-}

Language is a tool of communication that is used by human beings for their daily communication; if without language people could not be able to communicate and build a small group or even a community. By using this tool of communication people can understand each other among them through several characteristics such as word sounds, phrase, clause, sentence, symbol and sign. These show us that language is an agreement that is why the human beings have agreed the meaning of the sound agreement. One real example that make people never forget is teacher and students have an agreement on the sound ringing of the bell. It has been agreed among them and at the end they understand the meaning of the sound; says the school starts or the school finishes. "Language without

Corresponding Author:- Norberto Da Costa. Advisors.

Address:- S.Pd. M. App. Ling. Ph.D. Master Program in English Language Education Program. 
meaning is meaningless" Fromkin, (2005; p; 156),. People accept each other on the word meanings, phrase, clause and sentence meaning, symbols and sign meaning that they got, then in the syntax, semantics and grammar. Human beings could understand languages through arrangement meaning of the words and have relation among them.

On the other hand, people have many different existing languages which have been used as their spoken and written languages to solve their problems. They can not use these languages to solve the international problems. Therefore, they adopt English for the international language for their international communication to solve the world problems, such as economic, political, educational problems, and war, including Timor Leste's popular consultation in 1999. So, English is as a Lingua Franca as stated by Kolo in his book entitled ELF (2017). Meaning that almost people who come from different countries, not of English spoken backgrounds, can be united by the English language. In addition, Graddol (1997) stated: "English is the future of language, diplomacy and international communication, business, tourism, education science, computer technology, media and the internet, English is been used to develop communication, technology programming and software,' (p.23). Moreover, as an international language, English is used in a global sense for international communication between countries and in a local sense a language a wider communication within multi-lingual societies (Mackey, 2002, p.56).

In Timor Leste English is used as lingua Franca. The Timorese Parliament House, in its constitution, in part I, section 13 states that Portuguese and Tetun should be the national language of Republic Democratic of Timor-Leste, where Portuguese is the official language and Bahasa Indonesia and English should be the working or operational languages in Timor-Leste (RDTL Constitution, 2002, p.66). This means that the mentioned article above allows the Timorese people to study English language without any limitation. Based on this existing constitution, the Timorese government through, the Ministry of Education has designed a curriculum to include English for the whole school grades in Timor Leste. So, the students start to learn English from grade 4 or year 4 primary schools up to year 12 as a compulsory subject and a selective subject for university students.

\section{Research Questions:-}

Based on the writer's preliminary research done, at Escola Secundária Geral 4 de Setembro UNAMET Díli in the school year 2017, it is found that English speaking skill of the grade 12 of Escola Secundária Geral 4 de Setembro UNAMET Díli in the School year 2017, was relatively low.To improve this condition, the writer would like to carry out a Classroom Action Research (CAR) in treatment based on the title given, "The use of role play activities to improve speaking skill of the grade 12 students of Escola Secundária Geral 4 de Setembro UNAMET Díli in the school year 2017. This helped the writer to increase the ability of the forget students in speaking skills after treatment which was proud in post-

test.Therefore, the writer would like to formulate the problem above into the following questions. They are as follow:

1.1.1 How does the role-play activities improve students'speaking skills?

1.1.2 To what extent have the students' speaking skill improved after learning through role-play activities?

\section{Literature Review:- \\ Theoretical Concept of Speaking:-}

Speaking is so much a part of daily life (Thornbury, 2005, p.1).This idea is also emphasized by Bailey (2005) that, "speaking is such a fundamental human behavior. It means speaking is very essential in our lives," (p.2). It helps us to communicate among people in social life.Thus, Collins Australia Dictionary (2006) reinforces that speaking is to say words, talk, communicate or express in words, give a speech. While other expert, Florex (1999) states that, "speaking is an interactive process of construction meaning that involves producing and receiving and processing information," (p.1). It could be concluded that speaking assists us to communicate our thoughts, ideas, suggestions, and comments in our daily lives.

Then,Widdowson (in Makoni,2011) states that speaking skill is the activity and productive skill of language. While,Brown (2001) defines that speaking skill as a skill in producing oral language. The implementation of such a skill can be seen, for instance, when two or more people interact aimed at maintaining social relationship between them. While, according to Nuhan (2003) that, "Speaking is the productive aural/ oral skill which consists of producing systematic verbal utterance to convey meaning," (p.48). On the other hand, Gunther (1982) affirms that "speaking is not an automatic process but a form of human behaviors as complex as any other skill," (p.6.). 
According to Brown (as quoted in Makoni, 2011, p. 8), some priciples that should be concorded in teaching speaking skill, in teaching English speaking skill is no exception, are as follows: (1) focus on both fluency and accuracy, (2) provide intrinsic motivation technique, (3) encourage the use of authentic language in meaningful contexts, (4) provide appropriate feedback and correction, (5) Capitalizeon the natural link between speaking and listening, (6) give students opportunities to initiate oral communication, and (7) encourage the development of speaking strategies.

\section{Type of Speaking:-}

Harmer (1998, p, 284)states that four types of language feature in speaking; first connect speech, second expressive device, third lexis grammar and fourth negotiation language.

\section{Connect Speech:-}

Connect speech: effective speakers of English need to be able not only to produce the individual phonemes of English (as in saying I would have gone but also to use fluent connected speech (as in I'd've gone) in connected speech sounds are modified (assimilation), omitted (elision) added (linking), or weakened (through contractions and stress pattering).

\section{Expressive Device:-}

Expressive device : native speakers of English change the pith and stress of particular parts of utterances, vary volume and speed and show by other physical and non- verbal (paralinguistic) means how they are feeling, and they use of these devices contributes to the ability to convey meaning. They allow extra expression of emotion and intensity in face to face interaction.

\section{Lexis Grammar:-}

Spontaneous speech is marked by the use of a number of common lexical phrases, especially in the performance of certain language function.

\section{Negotiation language:-}

Effective speaking is benefited from the negotioatary language, we use to seek clarification and to show the structure of what we are saying and we often need to ask for

clarification when we are listening to someone else talk.

\section{Functions of Speaking:-}

Actually, speaking skill is a part of oral communication. Gillis (2013) states that the ability to speak skillfully provides the speaker with several distinct advantages. The capacity to put words together in a meaningful way to reflect thoughts, opinions, and feelings provides the speaker with these important advantages:

- $\quad$ Ability to inform, persuade, and direct. Business managers, educators, military

leaders, lawyers, and politicians, among others, seek to develop their speaking skills to such a level that they are transformed into master communicators. Speaking clearly and confidently can gain the attention of an audience, providing the golden opportunity for the speaker to make the message known. Wise is the speaker who gains and then holds the attention of an audience, with well-chosen words in a well-delivered presentation, forming a message that is effective, informative, and understood.

- Ability to stand out from the rest. When one thinks of speaking skills, one tends to think of it as a common skill. Think again. The ability to stand before others and speak effectively is not an ordinary ability. Many people are deathly afraid of public speaking; others have little ability to form thoughts into sentences and then deliver those words in a believable way. The bad news is that at any given moment the world has precious few with the speaking talents of, say, Winston Churchill or John F. Kennedy. The good news is that a speaker whose skills are honed and developed with constant application and hard work can stand out.

- Ability to benefit derivatively. Well-developed verbal skills can increase one's negotiation skills. Selfconfidence is improved. A growing sense of comfort comes from speaking in front of larger and larger audiences. A reputation for excellence in speaking can accrue over time, thereby imparting a certain credibility to the speaker.

On the other hand, Jack Richards's article as cited in Brown and Yule (1983) define two function of speaking. The first one is interactional functions of speaking, it meant to serve to establish and maintain social relations. While transactional functions of speaking focus on the exchange of information. 
http://www.cambridge.org/elt/blog/2016/02/teaching-speaking-2-styles-functions-speaking-talk-interaction/ Aside from this, the functions of teaching speaking skill play an important role to help the learners to communicate fluently. In addition, it also helps to create a classroom environment where students required to having real-life communication, authentic activities, and meaningful tasks that is needed to promote an oral skill. Therefore, the function of teaching speaking skills is vital in learning English as foreign language or second language in plenty of nation in the world including in Timor-Leste (TL).

In order to enhance students speaking skills, Harmer (2007, p. 123) states;

"There are three main reasons for getting students to speak in the classroom. Firstly, speaking activities provide rehearsal opportunities. It gives chance to practice real- life speaking safety of the classroom. Secondly, speaking tasks in which students try to use any or all of the languages they know provide feedback for both teachers and students. Finally, get tiny opportunities to activate the various elements of language they have stored in their brains." On the other hand, Sofia (2012) states, "Teaching speaking means giving the opportunity of students to study about how to combine the ideas and thought. Moreover, it is also about how students selecting the words, sentences orally which appropriate to their social setting. And teaching speaking is the way for student to make an interaction to another person in any situation," (p.6).

Moreover, Clark (1980) reveals that "teaching language technique to put student into realistic communication situation, sharpen their listening comprehension skills, bring them in contact with the new language and discover areas where they need additional practice," (p..55). In contrast, to enhance speaking skills in learning English as foreigner language and second language inquired many activities.

Hence, the article titled: "Introduction to the four skills of language," (p, 4). Explore seven (7) activities acquired by the learners to improve speaking skills in the process of learning English as foreign language:

1. Responding to Visual Clues (Picture and Words) aims:

To make students aware of the connections between visual and oral representation of language.

To encourage a more spontaneous use of language that the students know

2. Role play (students play a given role, with given opinion to talk about) aims:

To encourage students to use language they know,

To encourage students to speak, adapting given information and

To make students aware that they can use a language to say what they want.

3. Conversation aims:

To encourage real question and answers in context, and

To practice conversation skills and technique

4. Word Games aims;

To revise previously taught vocabulary or structures

To encourage students use the language they know spontaneously in new situations

To encourage fluency through competition,

To make learning fun.

5. Story building aims:

To give students practice in sequencing of events

To practice using sequencing words e.g. the, next afterwards

To give practice in retelling actions/situations in own words

6. Asking for and giving information (a real information gap where students each have

different of information) aims;

To give students practice in discovering what information is missing.

To guide students to forming questions

To elicit the information required

To give students practice in giving requested information.

7. Problem solving: aims:

To practice language of dis/agreement (I don't agree / disagree with you because)

To practice persuasive language (e.g "I think." and "Why don't we)

To give students a reason for speaking. 
From the explanation before, it could be understood that the function of teaching speaking inquired many activities to motivate students to improve speaking skills in learning language. However, in order to reach all the activities mentioned above come true, the role of the teachers in teaching speaking skill is extremely important.

\section{Role of Teacher in Teaching Speaking:-}

Thornbury (2015) affirms that "what do teachers need to know about language? He defines that language just like we would expect doctors to know a lot about medicine," (p, 10). Whereas, Harmer (2015) states that what are teachers really for? His personal reflections "If we can persuade students of the need to do something. And give them a powerful reason for doing it, and they have a very good chance of succeeding," (p, 19).

In addition, Lejla (2011, p.7 as cited in Penny Ur) about four characteristics for successful speaking activity as follows:

a. Learners talk a lot

b. Participation is even

c. Motivation is high

d. Language is of an acceptable level

From the above standpoints, it simply means that improving students' oral communication skills. Teacher talking time decrease and remember Students talking times should increase in learning speaking skills. For instance; teachers need to create situation where students get opportunities to speak and communicate with each other.

As it has been mentioned before, role play is one of the successful activities to motivate the learners to practice English fluency in learning English as foreigner language.

\section{Definition of Role Play:-}

Kumar (2012) states play is that activity through which child learns by doing with the least amount of resistance. It is a behaviour format which can facilitate report and communication and through which information and learning can pass between child and adult. The significance of play within, the human experience has been widely recognized and play is natural activity for children. It is a way in which children explore their environment and come to terms with its realities.

Actually, role play is learning technique in which you behave as somebody else would behave in certain situation. Islam (2012) mentions that, "role play is the medium which enables the students to get the ideas about different situation through various activities taken from the scenario of real life," (p, 219).

Thus, Sofia (as cited in Harmer, 1998, p. 94) states that role plays are an excellent way to get students interacting with one another and practicing target vocabulary in using real life scenarios. And role play lesson allows students to see and experience, how English can be used outside the classroom. And it helps to build student confident. She also asserts, "role play is a technique which can develop student fluency in target language, and promote students to speak or interact with others in classroom as wells as increase learners' motivation. And also make teaching learning process more enjoyable," (p.7).

Based on the explanation above, it could be defined that role play is a technique which gives language learners an opportunity to practise English skills in the classroom. At the same time, role play activity is to motivate students to be confident in talking or using English. In addition, it assists the learners to bring the real life situation into classroom. For example; students may pretend like; teacher and students at school, doctor and patient at hospital and costumer and waiterat the restaurant and so on.

\section{Types of Role Play:-}

LoveRoleplay (n.d.) points out that there are more possibilities of playing a roleplay online, like:

* Demon Roleplays contain dark powers, (half) demons and monsters. It's usually played with half demons, sons or daughters of demons and a human, as characters.

- Fantasy RPsare especially based on myths and mythical creatures like gods, angels, demons, fairies, et cetera. The difference with demon RPs is that fantasy RP contains all kind of magical creatures, not just demons.

* Normal RPsare based on real life, so no magic, powers or anything like that. 
* War Roleplay; the name already says what War RPs are about. You play that your characters are in a time of war. You can base it on historical wars, or ones that don't exist of haven't happened yet.

* Romantic RPs contain love. This type of RP can be played in combination with all the other types.

* Action RPs are like Action Movies, with missions and a certain goal.

* Sci-Fi RPs are RPs which are a genre of fiction with imaginative but more or less plausible content such as settings in the future, futuristic science and technology, space travel, parallel universes, aliens, and paranormal abilities.

* Adventure RPs are RPs in which a character or more characters take upon a journey and grow up with it, such as Pokémon.

* Comedy Roleplays are RPs which can be very funny and hilarious. This type of RP can be used with other types to be more hilarious. Example: with ecchi.

* Drama Roleplays contain drama, such as accidents, cheating, kidnapping, traumatic events, et cetera. This type of RP can be played with all other types of RPs.

* Ecchi Roleplay; Ecchi is a type of Japanese anime. It contains perverted boys, and a light form of sexual behavior or scenes. This type of RP can be played with all other types of RPs.

- Horror Roleplay; Horror is a type of Roleplay that can be very scary, such as using a scary story with ghost or horror plots.

* Animal Roleplay; Some think Animal Roleplay is a whole other category of roleplay. This can include furries, were-creatures, mythecal creatures, and just plain animals in role playing.

While, Susanti (as cited in Byne, 2007) mentions, "role play is divided into two types;

Scripted role play and unscripted role play," (p.16)

\section{Scripted Role Play:-}

Scripted meaning a broadcast that has been written in a text book before reading it. So, the main function of the text after all is to express the meaning of language items in a memorably way.Cambridge Advanced Learners Dictionary (2008). In this case scripted role play like dialogue, for more detail, Everyday Conversation America English gives an example about "Dialogue in informal greeting and farewells".

Jane: Hi, Helen How is it going?

Helen: Fine, thanks - and you?

Jane: Just fine, Where you off to?

Helen: To the library. I have got a history exam next week and

need start studying. Ugh.

Jane: Oh no, Well.. I will see you later then. Good Luck!

Helen: Thanks see you later.

To develop role play based on the dialogue provided by 900 Conversation America English book. Here teacher's task is to design procedure as follow:

a. Teacher guides the role play by speaking these key words: (asking condition/where to go?/library/ greeting / good luck/ thanks) talk as you write to show what the words mean.

b. If possible give opportunity for students to practice first with his/ her friends in pairs.

c. Call two students come to the front, one play the role as Jane and other play the role as Helen. They should make up the conversation using the prompt to help them; it could be similar to the dialogue or created new action with new vocabularies.

\section{Unscripted Role Play:-}

Meanwhile, Cambridge Advanced learners dictionary (2008) states that; unscripted describes a speech or broadcast that has not been written in the textbook before it is made. In this case, unscripted role play does not depend on the text books. It is known as a free role play or improvisation. The students themselves have to decide what language to use and how the conversation should develop.

In order to do this activity, good preparation from teachers and students is really necessary. Susanti (cited from Doffs, 2007) about the example and procedure of unscripted role play. (p,18).

"Talking at police station"

One student has lost a bag. 
$\mathrm{He} / \mathrm{she}$ is at the police station and the other student is the police officer, and asks for the details:

The teacher could prepare the whole class, by discussing what the speakers might say (example the police officer would ask the students how he or she lost the bag)

Teacher task is writing prompt on the board to guide the role play and key

vocabularies. The teacher could divide the student to work in pairs and discuss

together what they may say and let them try out role play privately, before call one

or two pairs to act in front of the class.

1.6 The Advantage and disadvantages of using Role Play in Teaching Speaking

2.7.1 Advantages of using Role Play in Teaching Speaking

1. In role playing the learners expresses feeling and attitudes Role playing encourages creativity

2. This method provides the learners with the opportunity to feel the situation rather than merely intellectualize about it.

3. The learners is motivated

4. Learners are being prepared for actual situations to be faced.

5. Role playing can be used to develop social skills.

6. A system of communication based on action rather than words is used. (Jone, et., 1994, p.1)

2.7.2 The Disadvantage of using Role Play in Teaching Speaking

1. Learners sometimes emphasize performance over the intended lesson

2. Role playing is time consuming

3. Some learners are unable to identify with the character or situation

4. Learners often get "carried away" in their roles, which can lead disruption of the class or distortion of the learning.

5. "Hot topics" and controversial issues often get out of hand in role-playing. (Jone, et., 1994, p.1)

(Disadvantages) According to Kolo $(2008$, p. 2) the problems in speaking skill are follows: (1) inhibitation: worried about making mistakes, fearful of criticism or losing face, or simply shy of the attention that their speech attracts; (2) nothing to say: they cannot think of everything to say: they have not motives to express themselves beyond the guilty feeling that they should be speaking; (3) low or uneven participation: there is a tendency of some learners to dominate, while ather speakers very little or not at all; and (4) mother-tongue use: if they are practice speaking in small groups, it can be quite difficult to get some students-particularly the less disciplined or motivated ones-to keep talking in the target language (Brown, 1994).

Every students has his or her own difficulties in learning English. Based on the writer's experience, the students were woried in making mistakes, nervous, and embarrased when they were asked to speak English. When the teacher asked them to practice, they tend to use Tetun language or they just keep silent. They did not want to speak in English because if they made mistakes their friends laughed at them and that condition made them shy to speak English. In this case, teachers should build students' confidence by encouraging them that making mistake is something usual but by making mistake they get and learn something.

\section{Research Methodology:-}

\section{Research Design:-}

De Vaus (2001) refers the research design as the overall strategy chosen to integrate the different components of the study in a coherent and logical way, thereby, ensuring that it will effectively address the research problem. It constitutes the blueprint for the collection, measurement, and analysis of data that may interfere with the validity of the findings (Burns and Grove, 1993).

In this study, the research design generally constitutes of the research design, the subject of the study, the procedure of data collection, the instruments of data collection, methods used for data analysis, technique of data analysis, technique of data presentation, and the time allocation.

Moreover, the writer used the classroom action research design to address the research problem, as defined below: 


\section{Action Research Design:-}

According to Arikunto (2006) that an action research is characterized as reflective participative, collaborative and cyclical research design whereby initially an exploratory stance is adopted, where an understanding of a problem is developed and plans are made. In addition, action research is "learning by doing" in which a person identifies a problem, does something to resolve it, see how successful his or her efforts were, and if not satisfied do it again the second time (O’Brian, 1998).

A German social and experimental psychologist, Kurt Lewin, is generally considered as the father of action research design (O’Brian, 1998). There are several types of action research introduced by Lewin. However, in this study the writer would like to focus on the use of classroom action research.

Classroom action research is a classroom based research. McNiff (1994) states that action research when applied to classroom research is an approach to improve education through change, by encouraging teachers to be aware of their own practices, to be critical of that practices, and to be prepared to change it.

\section{Location of Research:-}

The writer carried out this study at Escola Secundária Geral 4 de Setembro UNAMET Díli, because:

1. it is one of the public senior high schools in the capital Díli located under administrative city of Díli municipality which is total students 2.632, higher than other secondary schools in Timor Leste.

2. The writer chose the grade 12 students of technology science because the writer wants to know their ability in learning English at refered school during two years by using a sertain method of teaching.

3. The last writer wants to use role play activity to compare with the old method used.

\section{Research Subject:-}

This study was carried out at Escola Secundária Geral 4 de Setembro UNAMET Díli in the school year 2017. Therefore, the subjects of this study are the students of Escola Secundária Geral 4 de Setembro UNAMET Díli in the school year 2017 .

So, the source of this study, the writer chose the grade 12 students of Escola Secundária Geral 4 de Setembro UNAMET Díli in the school year 2017, that consists of eight parallel classes and each class is alphabetically labelled such as class A, B, C, D, E, F, G and H of technology science.

Therefore, the researcher chose the students randomly from eight (8) parallel classes. The writer planned to select four (4) students from each class. So, the total numbers were 32 informants in this study.

\section{Research Procedures:-}

Generally, action research is cyclic. In the classroom action research, it has two cycles. They are cycle one and cycle two. Each cycle is covering the four components of planning, acting, observing, and reflecting. This methodology is used by the writer to find out the improvement of using role play activity in improving the students' speaking skill. Below is the model of Action Research Spiral as introduced by Lewin (2017).

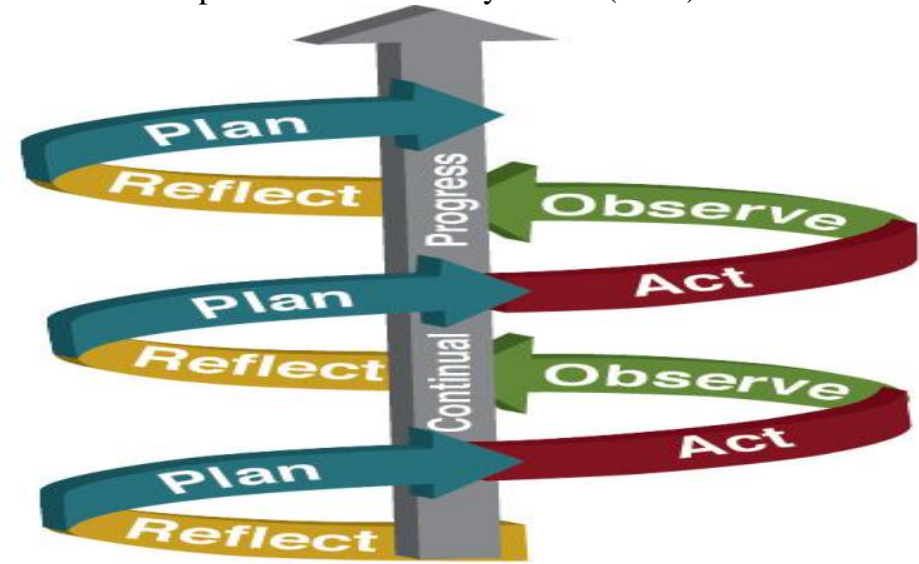

According to the spiral model above, a classroom action research is divided into two cycles. Each cycle has four stages of activity, namely: planning, acting, observing, and reflecting. In this case this action research will help the 
writer to find out the improvement of speaking ability of grade 12 students of Escola Secundária Geral 4 de Setembro UNAMET Díli in the school year 2017 by using role play.

In this section, the writer collected the data from two sources. They are library research and field research.

The writer has divided the action or treatment into four parts such as planning, acting, observing/evaluating and reflecting; and they are presented as follow:

1. Planning

- The researcher prepared treatment actions to be implemented during the experiment. All of the teaching and learning actions were written in lesson plans. In accordance with the classroom actions the researcher also prepared relevant materials and media.

- To monitor how the role-play gives its affects to students speaking ability, the researcher also prepared a check list rubric and scoring instrument. The classroom observation rubric is intended to observe the learners' learning behaviors that are reflected in their actions while following the lessons.

$\bullet$

2. Acting

In acting stage the researcher began his treatment according to the actions which had been written in the planning stage. All of the actions should be carefully implemented in order to see if the actions give positive results to students' learning.

\section{Observing}

The job to observe how teaching-learning take place was done by the teacher-collaborator who in this research is the real English teacher of the target class. The collaborator's job consists of two: observing learner's activeness and scoring their speaking ability which was done one in each cycle. At every observation task, the collaborator produced two kinds of data: data about learner's learning behavior, and learner's speaking results.

\section{Reflecting}

The researcher made reflection based on the results of the observation since and the speaking test. The researcher commented on the aspects which were still problematic and those which already showed improvement. At the end the researcher gave his recommendation. Based on the his recommendation, the classroom action research was carried out in two cycles only. The first cycle consisted of three class meetings and the second cycle only two. After the second meeting action was completed the researcher evaluated the results and he came to a conclusion that the treatment be stopped.

\section{Data Collection Technique:-}

Actually there were more than one method the researcher used to collect data. Due to the fact that the research problem did not come from the researcher's own experience, it was necessary for him to retrieve problems from fellow English teachers in the school. To do this, he conducted some informal interviews with the school English teachers and some students from the target class. In addition, he also conducted an informal observation in the target class and gave the students a pretest. All information obtained from this preliminary activities revealed the learning problems that became the basis of this classroom action research.

\section{Research Instrument:-}

In this research there were only two instruments used to collect data, they were observation rubric checklist and speaking test scoring guidance. Each of the instruments is presented below:

\section{Checklist Rubric for Classroom Observation}

\begin{tabular}{|l|l|l|l|}
\hline No. & Indicator & \multicolumn{2}{|l|}{ Implementation } \\
\cline { 3 - 4 } & & Yes & No \\
\hline 1. & Students are well prepared for the teaching learning process & & \\
\hline 2. & $\begin{array}{l}\text { Students take notes of teacher's explanation related to the objectives of the } \\
\text { teaching learning process }\end{array}$ & & \\
\hline 3. & Students actively divided themselves in groups to carry out any learning tasks & & \\
\hline 4. & Students actively share knowledge to one another in their group & & \\
\hline 5. & Students actively help one other for best performance & & \\
\hline
\end{tabular}




\begin{tabular}{|l|l|l|l|}
\hline 6. & Students use English language during teaching learning process & & \\
\hline 7. & Students enthusiastically come forward before the class for demonstration & & \\
\hline 8. & $\begin{array}{l}\text { Students get nervous, shy and uncomfortable when invited to demonstrate a } \\
\text { role-play in front of the class }\end{array}$ & & \\
\hline 9. & Students voluntarily do a role-play demonstration in front of the class & & \\
\hline 10. & Students spoke loudly and clearly in the front of classroom & & \\
\hline 11. & Students speaking practice runs smoothly & & \\
\hline 12. & Students speaking test runs smoothly according to the plan & \\
\hline
\end{tabular}

Adapted from: Agib, Zainal. 2009.

Table 1:- Rubric Scale for Testing Student Speaking Skills

\begin{tabular}{|c|c|}
\hline \multicolumn{2}{|c|}{ 1. Team Working (T.W.) } \\
\hline $86-100 \%$ & Helping each other from the beginning until the end of showing the performance \\
\hline $71-85 \%$ & Helping each other but not well prepared in team working \\
\hline $56-70 \%$ & Less in helping each other \\
\hline$<55 \%$ & No team working \\
\hline \multicolumn{2}{|c|}{ 2. Fluency $(\mathbf{F})$} \\
\hline $86-100 \%$ & Speech is smooth, flowing and understandable \\
\hline $71-85 \%$ & Speech is smooth but less understanding the content \\
\hline $56-70 \%$ & Speech stuck but understandable \\
\hline$<55 \%$ & no fluency \\
\hline \multicolumn{2}{|c|}{ 3. Vocabulary (V) } \\
\hline $86-100 \%$ & $\begin{array}{l}\text { Uses vocabularies from present.conti. (nominal form uses to be without mean verb and verbal } \\
\text { form uses to be present }+ \text { mean verb }+ \text { ing }+ \text { o/adv.and etc. And time signal; include with five } \\
\text { sense words like fill, see, listen, think, test, and like, want, love and etc. }\end{array}$ \\
\hline $71-85 \%$ & Uses many vocabularies but less to be present $+v+$ ing and time signal \\
\hline $56-70 \%$ & Less vocabularies, less adding “ing”and less time signal \\
\hline$<55 \%$ & No vocabularies, no adding "ing" and no time signal \\
\hline \multicolumn{2}{|c|}{ 4. Grammar of Present Continuous (G.P.C.) } \\
\hline $86-100 \%$ & $\begin{array}{l}\text { Uses to be present }(\mathrm{S}+(\mathrm{am}, \text { is, are })+\mathrm{v}+\mathrm{ing}+\mathrm{o} / \mathrm{adv} \text {; afirmative, negative and interrogative } \\
\text { sentences and no error grammar }\end{array}$ \\
\hline $71-85 \%$ & Uses to be present but less of affirmative, negative and interrogative sentences \\
\hline $56-70 \%$ & less of to be present and affirmative, negative and interrogative \\
\hline$<55 \%$ & no present continuous tense \\
\hline \multicolumn{2}{|c|}{ 5. Pronunciation $(\mathbf{P})$} \\
\hline $86-100 \%$ & No errors in pronunciation that impede comprehension. \\
\hline $71-85 \%$ & A few errors in pronunciation rarely impede comprehension. \\
\hline $56-70 \%$ & Not really good pronunciation \\
\hline$<55 \%$ & Do not understand the pronunciation at all. \\
\hline \multicolumn{2}{|c|}{ 6. Self-Esteem (S.E) } \\
\hline $86-100 \%$ & Good confident, eyes Contact, body language and loud voice \\
\hline $71-85 \%$ & Good confident and eyes Contact, but no body language, and loud voice \\
\hline $56-70 \%$ & Less confident and less eyes Contact, body language, and loud voice \\
\hline$<55 \%$ & No self-esteem \\
\hline
\end{tabular}

Adapted from: Arikunto 2007

Technique of Data Analysis:-

There were two kind of data analysis used in this action research. One technique belongs to qualitative analysis and the other to quantitative analysis. The qualitative analysis is done to classroom observation data in which the analysis is based on the growing trends toward the majority of students, and the quantitative analysis to speaking test data is based on calculation of mean score first of each speaking component and then the overall using the following formula. 
To get the mean can be used the following formula:

$$
\mathrm{X} \quad \frac{\delta \mathrm{X}}{\varepsilon \mathrm{N}}
$$

Notes: $\mathrm{X} \quad \square \quad=$ The Mean

$\Sigma \mathrm{X}=$ The total of the whole scores of testee

$\Sigma \mathrm{N} \quad=$ The total testee who follow the test

Next, to understand the level of students' speaking ability the mean score of the total score was matched with the following classification by Arikunto (2001).

\begin{tabular}{|l|l|l|}
\hline No & Score & Level of Speaking Ability \\
\hline 1 & $86-100 \%$ & Very High \\
\hline 2 & $71-85 \%$ & \multicolumn{1}{c|}{ High } \\
\hline 3 & $56-70 \%$ & Average \\
\hline 4 & $41-55 \%$ & Very Low \\
\hline 5 & $<40 \%$ & \\
\hline & Range $15 \%$ & \\
\hline
\end{tabular}

\section{Data Analysis And Discussion:- \\ School Profile:-}

Escola Secundária Geral 4 de Setembro UNAMET Díli is one of the public senior high schools that is located in the capital of Timor Leste under administrative city of Díli Municipality. There are 2636 students who study at the school this year and they are divided into 50 classes and each class consists of 52 students. The school has 116 teachers and 10 of whom are English teachers. According to data taken from Ministery of Education in 2017, Escola Secundária UNAMET Díli has the most students of all schools in Timor Leste.

\section{Research Description:-}

The research was conducted in three phases, preliminary research, cycle-one treatment, and cycle-two treatment. The preliminary research was conducted in order for the researcher to be able to identify problems commonly faced by the English teachers. For the researcher, one of these problems might be intresting enough to do a classroom action research as a solution. It was conducted by means of interview (English teachers and students) and classroom observation. Based on the results of the prelimiary research the researcher moved on to treatment which consists of two cycles. Details the research activity is described in the following.

\section{Preliminary Research:-}

On top of the questions from the interview with the English teachers, it is pointed out that the level of students' speaking skills was relatively low, even some students could not answer simple questions such as "Where do you live?" or "Where do you come from?" The fact that they were not good enough at speaking because they usually did not participate at all during speaking practice. For examples, during English classes students rarely ask questions in English, let alone give suggestions or comments. Furthermore, the English teachers also said that they have not conducted any speaking evaluation until then because they thought that evaluation was only done in written form during mid and semester tests.

Aside from interviewing of the English teachers, the researcher also interviewed three students, two students from Class A of grade 12, and one class B the same grade. They were asked how they thought about their English class and whether or not they were given an opportunity to practice speaking. From the interview it was revialed that they did not practice how to speak English during the English class, that they were too shy to speak because their English would sound funny, that they were afraid to make mistakes so that their friends would laugh at them, and that they thought they lacked of vocabulary. One interesting reason why students lack of motivation to learn English was because people around the students never said that English is important for future life.

However, the students agreed that there were just few students in the class who were active in following the English lesson. When the teacher asked the class to do group work and they successfully presented their work in front of the class, but many more students were not able to do so because they suddenly became nervous, fearful and finally got stuck completely. 
From the preliminary study the following problems were identified:

- Despite their high grade, the level of students' speaking skill can be categorized as beginners or in other words they are still at elementary level.

- The English teachers hardly ever provide opportunity for the students to opractice how to speak English during the English class.

- The students think that they are not able to speak English because they are afraid or shy of making mistakes or when their friends laughed at them or when their English sounds funny.

- The students actually have wanted very much to speak English and have questioned themselves why.

- No one person around the students has ever said that English is important for their future life.

- In addition to the interview, the reseacher thought that it would be a necessity to conduct a pretest on students' speaking ability in order to know their existing ability before conducting the classroom action research. In this test the researcher asked the class teacher to become his colaborator and scored the students, performance using the instrument which he had prepared. The test was very simple in which the researcher only asked the students one by one to come forward to describe one of the pictures that the researcher had posted on the wall. The two pictures are identical showing situations of an English class. In describing the picture the reseacher prompted the testee with four questions: What are the students doing in the picture?; What is the teacher doing?; What are the students reading? Can you mention any objects that you see in the picture? While the student answering the questions, the teacher-collaborator scored each criterion on a rating scale from 10 to 100 . The result of the pretes is reported in the following table.

Table 1:- Scores of Students' Speaking Ability from Pretest

\begin{tabular}{|c|c|c|c|c|c|c|c|c|}
\hline \multirow[t]{2}{*}{ No } & Grammar & Vocabulary & Pron & Fluensy & $\begin{array}{l}\text { Team } \\
\text { Work }\end{array}$ & $\begin{array}{l}\text { Self- } \\
\text { Esteem }\end{array}$ & $\begin{array}{l}\text { Total } \\
\text { Score }\end{array}$ & Average \\
\hline & 1 & 2 & 3 & 4 & 5 & 6 & 7 & 8 \\
\hline 1 & 58 & 82 & 70 & 70 & 72 & 72 & 424 & 70.66 \\
\hline 2 & 57 & 76 & 68 & 70 & 76 & 73 & 420 & 70 \\
\hline 3 & 57 & 77 & 65 & 70 & 75 & 75 & 419 & 69.83 \\
\hline 4 & 58 & 80 & 68 & 70 & 70 & 70 & 416 & 69.33 \\
\hline 5 & 48 & 66 & 65 & 65 & 68 & 70 & 382 & 63.66 \\
\hline 6 & 56 & 60 & 66 & 60 & 70 & 65 & 377 & 62.83 \\
\hline 7 & 58 & 60 & 60 & 65 & 60 & 70 & 373 & 62.16 \\
\hline 8 & 60 & 62 & 68 & 58 & 65 & 55 & 368 & 61.33 \\
\hline 9 & 55 & 60 & 65 & 60 & 62 & 60 & 362 & 60.33 \\
\hline 10 & 60 & 73 & 68 & 55 & 48 & 56 & 360 & 60 \\
\hline 11 & 50 & 56 & 60 & 56 & 68 & 70 & 360 & 60 \\
\hline 12 & 55 & 56 & 60 & 62 & 64 & 60 & 357 & 59.5 \\
\hline 13 & 45 & 56 & 66 & 57 & 60 & 71 & 355 & 59.16 \\
\hline 14 & 62 & 56 & 66 & 56 & 56 & 56 & 352 & 58.66 \\
\hline 15 & 65 & 65 & 68 & 45 & 48 & 56 & 347 & 57.83 \\
\hline 16 & 56 & 56 & 56 & 60 & 58 & 58 & 344 & 57.33 \\
\hline 17 & 50 & 56 & 50 & 48 & 56 & 44 & 304 & 50.66 \\
\hline 18 & 50 & 50 & 48 & 45 & 44 & 50 & 287 & 47.83 \\
\hline 19 & 50 & 52 & 42 & 45 & 48 & 45 & 282 & 47 \\
\hline 20 & 52 & 48 & 42 & 45 & 46 & 48 & 281 & 46.83 \\
\hline 21 & 51 & 50 & 58 & 45 & 45 & 50 & 299 & 49.83 \\
\hline 22 & 50 & 48 & 46 & 45 & 49 & 48 & 286 & 47.66 \\
\hline 23 & 52 & 50 & 60 & 45 & 45 & 48 & 300 & 50 \\
\hline 24 & 58 & 60 & 66 & 58 & 48 & 45 & 335 & 55.83 \\
\hline 25 & 55 & 50 & 50 & 48 & 46 & 46 & 295 & 49.16 \\
\hline 26 & 48 & 45 & 50 & 42 & 45 & 44 & 274 & 45.66 \\
\hline 27 & 46 & 48 & 52 & 49 & 42 & 42 & 279 & 46.6 \\
\hline 28 & 50 & 60 & 50 & 45 & 50 & 48 & 303 & 50.5 \\
\hline 29 & 50 & 45 & 45 & 52 & 48 & 44 & 284 & 47.33 \\
\hline 30 & 48 & 46 & 48 & 48 & 50 & 48 & 288 & 48 \\
\hline
\end{tabular}




\begin{tabular}{|l|l|l|l|l|l|l|l|l|}
\hline 31 & 48 & 45 & 48 & 48 & 45 & 50 & 284 & 47.33 \\
\hline 32 & 62 & 66 & 66 & 67 & 68 & 65 & 394 & 65.83 \\
\hline Total & 1720 & 1860 & 1860 & 1757 & 1795 & 1802 & 4381 & $1,798.66$ \\
\hline Average & 53.75 & 58.125 & 58.125 & 54.90 & 56.09 & 56.31 & 1224 & 56.20 \\
\hline
\end{tabular}

The table shows the mean score falling in the range within 50's which is categorized as average.

Table 2:- Results of Classroom Observation in Cycle One

\begin{tabular}{|c|c|c|c|}
\hline \multirow[t]{2}{*}{ No } & \multirow[t]{2}{*}{ Indicator } & \multicolumn{2}{|c|}{ Implementation } \\
\hline & & Yes & No \\
\hline 1. & The students are well prepared for the teaching learning process & $\mathbf{x}$ & $\mathbf{X}$ \\
\hline 2. & $\begin{array}{l}\text { The students take note of teacher's explanation related to the objectives of the } \\
\text { teaching learning process }\end{array}$ & $\mathrm{x}$ & \\
\hline 3. & The students actively divided themselves in group to carry out any learning tasks. & $\mathrm{X}$ & \\
\hline 4. & The students actively share knowledge to one another in their group & $\mathrm{X}$ & $\mathrm{X}$ \\
\hline 5. & The students actively help one other for best perfomance & $\mathrm{x}$ & $\mathrm{X}$ \\
\hline 6. & The students used English language during teaching learning process & $\mathrm{X}$ & $\mathrm{X}$ \\
\hline 7. & The students enthusiastically come forward before the class for demonstration & $\mathrm{X}$ & $\mathrm{X}$ \\
\hline 8. & $\begin{array}{l}\text { The students get nervous, shy and uncofortable when invited to demontrate a role - } \\
\text { play in front of the class }\end{array}$ & $\mathrm{X}$ & $\mathrm{X}$ \\
\hline 9. & The students' voluntarily do a role-play demonstration in front of the class & $\mathrm{X}$ & $\mathrm{X}$ \\
\hline 10. & The students spoke loudly and clearly in the front of the classroom & $\mathrm{X}$ & $\mathrm{X}$ \\
\hline 11. & The students speaking practice runs smoothly & $\mathrm{X}$ & \\
\hline 12. & The students speaking test runs smoothly according to the plan & $\mathrm{x}$ & $\mathrm{X}$ \\
\hline
\end{tabular}

X: Majority

As appear in the table, there is a small check $(\mathrm{x})$ and there is also a bigger check $(\mathrm{X})$ which indicate occurance of an event or phenomenon. The small check indicates that the occurance of an event or phenomenon has been detected in the class in more or less frequency, whereas the bigger check indicates a growing trend of the event or phenomenon towards the majority of students. For example, in coloumn 1 'Students are well prepared for the teaching-learning process', there are two checks, one is small and the other is big. The interpretation of this coloumn is that there is apparantly evident that majority of students in the class have prepared themselves well and so are now ready both physically and emotionally to be taught by the teacher.

As has been exhibited in the table, the data of the classroom observation can be interpreted negatively in terms of students' activenes. It seems that the students always rely on the teacher interference to make them active. They become very dependent and need continuous push or encouragement from the teacher. They tend to exhibit a "wait and see" attitude rather than taking initiatives to begin practicing or demonstrating a role-play. To summarize some of the students show positive results, whereas the majority do not.

As mentioned earlier that there is another data i.e. the scores of the students' speaking test. The students' speaking skills were evaluated in terms of six components, which are grammar, vocabulary, pronunciation and word stress, fluency, team-work, and self-esteem. The scoring system of each component starts from 10 as the lowest up to 100 as the highest. The results of the students' speaking test in cycle one is presented in the following.

The results of the students' speaking test in cycle one is presented in the following.

Table 3:- Students' Scores of Role-Play Performance of Cycle One

\begin{tabular}{|l|l|l|l|l|l|l|l|l|}
\hline \multirow{2}{*}{ No } & Grammar & Vocabulary & Pron & Fluensy & $\begin{array}{l}\text { Team } \\
\text { Work }\end{array}$ & $\begin{array}{l}\text { Self- } \\
\text { Esteem }\end{array}$ & $\begin{array}{l}\text { Total } \\
\text { Score }\end{array}$ & Average \\
\cline { 2 - 9 } & 1 & 2 & 3 & 4 & 5 & 6 & 7 & 8 \\
\hline 1 & 68 & 88 & 80 & 82 & 88 & 88 & 494 & 82.33 \\
\hline 2 & 70 & 88 & 78 & 83 & 87 & 88 & 494 & 82.33 \\
\hline 3 & 72 & 90 & 78 & 80 & 84 & 84 & 488 & 81.33 \\
\hline 4 & 72 & 90 & 82 & 82 & 84 & 84 & 494 & 82.33 \\
\hline
\end{tabular}




\begin{tabular}{|l|l|l|l|l|l|l|l|l|}
\hline 5 & 68 & 76 & 78 & 77 & 86 & 78 & 463 & 77.16 \\
\hline 6 & 60 & 82 & 80 & 80 & 78 & 86 & 466 & 77.66 \\
\hline 7 & 72 & 76 & 75 & 76 & 76 & 85 & 460 & 76.66 \\
\hline 8 & 72 & 76 & 80 & 70 & 81 & 71 & 450 & 75 \\
\hline 9 & 80 & 78 & 80 & 58 & 58 & 70 & 424 & 70.66 \\
\hline 10 & 72 & 82 & 78 & 70 & 62 & 70 & 434 & 72.33 \\
\hline 11 & 64 & 76 & 63 & 62 & 75 & 62 & 402 & 67 \\
\hline 12 & 61 & 58 & 62 & 58 & 58 & 62 & 359 & 59.33 \\
\hline 13 & 63 & 62 & 56 & 56 & 61 & 62 & 360 & 60 \\
\hline 14 & 63 & 58 & 58 & 57 & 58 & 60 & 354 & 59 \\
\hline 15 & 65 & 65 & 70 & 58 & 57 & 55 & 370 & 61.66 \\
\hline 16 & 62 & 62 & 59 & 59 & 62 & 60 & 364 & 60.66 \\
\hline 17 & 62 & 61 & 70 & 56 & 58 & 60 & 367 & 61.16 \\
\hline 18 & 68 & 70 & 76 & 69 & 56 & 58 & 397 & 66.16 \\
\hline 19 & 60 & 55 & 56 & 58 & 56 & 56 & 341 & 56.83 \\
\hline 20 & 60 & 58 & 58 & 56 & 55 & 56 & 343 & 57.16 \\
\hline 21 & 61 & 60 & 62 & 60 & 57 & 56 & 356 & 59.33 \\
\hline 22 & 60 & 61 & 60 & 57 & 59 & 58 & 355 & 59.1 \\
\hline 23 & 61 & 66 & 58 & 57 & 56 & 56 & 354 & 59 \\
\hline 24 & 68 & 68 & 69 & 70 & 72 & 72 & 419 & 69.83 \\
\hline 25 & 67 & 56 & 56 & 66 & 58 & 57 & 360 & 70.5 \\
\hline 26 & 76 & 66 & 78 & 67 & 68 & 68 & 423 & 70.5 \\
\hline 27 & 56 & 68 & 78 & 68 & 72 & 82 & 424 & 70.66 \\
\hline 28 & 60 & 64 & 72 & 67 & 78 & 78 & 419 & 69.83 \\
\hline 29 & 58 & 58 & 57 & 58 & 59 & 58 & 348 & 58 \\
\hline 30 & 65 & 66 & 70 & 72 & 72 & 72 & 417 & 69.5 \\
\hline 31 & 58 & 56 & 58 & 58 & 56 & 60 & 346 & 57.66 \\
\hline 32 & 66 & 68 & 70 & 73 & 74 & 68 & 419 & 69.83 \\
\hline Total & 2029 & 2208 & 2205 & 2120 & 2219 & 2180 & & 2170.49 \\
\hline Avera & 63.40 & 69 & 68.90 & 66.25 & 69.34 & 68.12 & & 67.82 \\
\hline & & & & & & & & \\
\hline
\end{tabular}

\section{Reflecting:-}

It seems that the first activity, the dialog rehearsal, is quite effective in building students' motivation as well as boosting their self-confidence. Rehearsing the final scene of the dialog before coming to the evaluation session is the right thing the teacher has done. Nevertheless, involving the class playing one role and the teacher another role has successfully eliminated students' anxiety and therefore made them ready for the evaluation.

Although the rehearsal has a positive effect to students, not all them had performed well during the evaluation. The awkwardness of some students is understandable due to the fact that the students have not any experience being evaluated on their speaking ability ever since they learned English at school. The mean score of student's evaluation shows a convincing evidence of a link between frequent exposure to English speaking and the ability of speaking. If only they were given a second chance, surely the students would perform much better than today's performance.

From the table it is clear that two components show the lowest score scores i.e. below 1000 compared to other components which score above 1000. The mistakes of the grammar component in this performance are mainly caused by the use of simple past tense especially the irregular verbs, whereas the fluency component is caused by the fact that some students had forgotten their lines and were able to complete their performance only after guided by the teacher. Although in general the students' mean score has been classified as 'good', the students based on their motivation and enthusiasm could have scored more than this one. Finally, the researcher concluded that the experiment of role-play to increase students' speaking ability be continued to the second cycle.

\section{Cycle Two:-}

An especially interesting area that has been demonstrated by students during the first cycle is that the students began showing great enthusiasm to practice speaking English. Now the researcher has to remind the English teachers of the school that the students may not ever lose their enthusiasm for learning English in the future. The English teachers in witnessing the resarcher employing the role-play strategy have recognized the need to continue their teaching by 
regularly providing speaking practice for their students. The value of maintaining students' motivation lies in their power to alter their perspectives on teaching that in the future they should employ variety of innovative models of teaching including the use of role-play.

Believing in the usefulness of the role-play during the first cycle, the researcher consider the expansion of the same dialog instead of replacing it with a new one. In this case the same situational English will be further developed by incorporating many more language items especially grammar and vocabulary. Despite the apparently strong evidence that the students have gained a fairly good speaking ability, the results of the observation has revealed some awkward behaviors of a significant number of pairs during the evaluation. Therefore, in this cycle the reseracher will pay more focus on the less improved components of fluency and team-work. All treatment activities of Cycle Two are described below.

Cycle Two treatment was carried out in two class meetings only. The first class meeting was particularly intended to provide students with new inputs in terms of related language items about illness and the second one was designed merely for students demonstration of the extended conversations. The demonstration of the extended conversation was valued as speaking test and therefore was evaluated by the collaborator. Unlike report on cycle one, all of the treatment activities of both meeting one and two will be written in one report only as presented below. This is due to the fact that the meeting one activities in this cycle was diseigned for treatment which will be evaluated during the speaking test in meeting two.

The main objective of meeting one is that students would learn some new language items which are still related to the same situation. The new language items are believed to help facilitate students to expand their conversation when talking about illness. The objectives of meeting two, on the other hand, will focus on the retention of the newly learned language items and their application in a new situation provided by the teacher. The new situation must not be completely unfamuliar to students but the one who is already known before. In this case, the new situation would be still about visiting a doctor either at the hospital or other place where the doctor receives and treats patients.

\section{Planning:-}

To have an effective treatment the reseacher has designed the following actions that he will employ in the two class meetings.

- Reviewing the previously learned language items.

- Introducing new language items which are still related to illness. These include grammatical structure such as present continuous tense, present perfect tense, and modal verbs can, may, must, shall, will, might, and vocabulary about illness such as cold, influenze, fever and malaria, sore throat, and running nose.

- Designing pair practice with new language items.

- Demonstrating expanded conversation by the researcher acting as a doctor and a student as patient.

- Demonstrating expanded conversation again but now the researcher still acts as doctor and a student speaking for a patient who is a relative. In this sense, the student will act as an interpreter for a sick relative who does not speak English. It is in this demonstration, the collaborator will take scores.

\section{Acting:-}

The researcher began his class with a review of the language items that the students have learned and used to substitute certain parts of the original dialog in cycle one class meetings. At first, he asked the students to mention kinds of illness they have learned, then he asked the class "What happens when you have a headache/stomachache/toothache?", and finally the reseacher began to play a role with the class, sometimes as a doctor and sometimes as a patient and he let any student from the class either answer as patient or respond as a doctor. In playing these roles the reseacher intentionally used again other language expressions such as 'I couldn't sleep at all last night', 'I must take three tablets a day after meals' ,' How do you feel today?', etc.

During the initial practice in meeting one, the researcher switched roles where he himself played the role of the doctor and the students as the patient. In this game the researcher would hold the control of the dialog to allow the possibility to explore further about the patient's illness. By doing so, the student playing the role of the patient is forced to demonstrate more language when he or she wants to describe about the illness. Upon the application of actions in meeting one, the researcher has the option of nominating certain students (usually the able ones) to play role of a patient with the researcher himself who played the role of a doctor. While four students were selected to 
play roles with the researcher, a simple relationship may nonetheless hold between inputs and application. This means that if what is newly learned (input) is to be immediately applied in new situation, the inputs will be permanently retained in the long-term memory. Students now practice their speaking skill with a wider range of language, although in limited topic.

Coming to meeting three, both the teacher and the students demonstrated high expectation of having excellent performance during the speaking test. The forty-five minutes class was spent for the speaking test only. Two other teachers were also invited to join the class, one is the collaborator who will take scores on students' performance, and the other is the one who will act as real patient. At first the researcher explained the mechanism of the speaking test in which the conversation would take place between a doctor and a student who would speak for a sick relative. Next, the researcher picked up the attendance list and announced that the first name in the list would start the speaking test first. The researcher decided that each student would take approximately two minutes to perform. The reseacher set up an artificial office of a general practitioner (GP) by arranging one table and three seats. One of the seats would be prepared for the doctor and the other two for the patient and the interpreter. The researcher finally finished the speaking test with a positive impression on the students' performance.

\section{Observing:-}

The collaborator observed the class twice, each for every class-meeting. The first observation was mainly done based on the students' participation in following the lesson and the second one at their performance during the speaking test. For the sake of data analysis of the reserch, the resluts of the two reports were combined in one report only. As to both observations, the results were analyzed qualitatively instead of an analysis in percentage terms. Here is the report of the observation results of cycle one.

Table 4:- Results of Classroom Observation in Cycle Two

\begin{tabular}{|c|c|c|c|}
\hline \multirow[t]{2}{*}{ No } & \multirow[t]{2}{*}{ Indicator } & \multicolumn{2}{|c|}{ Implementation } \\
\hline & & Yes & No \\
\hline 1. & The students are well prepared for the teaching learning process & $\mathbf{x}$ & \\
\hline 2. & $\begin{array}{l}\text { The students take note of teacher's explanation related to the objectives of the } \\
\text { teaching learning process }\end{array}$ & $\mathrm{X}$ & \\
\hline 3. & The students actively divided themselves in group to carry out any learning tasks. & $\mathrm{x}$ & \\
\hline 4. & The students actively share knowledge to one another in their group & $\mathrm{X}$ & $\mathrm{x}$ \\
\hline 5. & The students actively help one other for best perfomance & $\mathrm{X}$ & $\mathrm{x}$ \\
\hline 6. & The students used English language during teaching learning process & $\mathrm{X}$ & $\mathrm{x}$ \\
\hline 7. & The students enthusiastically come forward before the class for demonstration & $\mathrm{X}$ & $\mathrm{x}$ \\
\hline 8. & $\begin{array}{l}\text { The students get nervous, shy and uncofortable when invited to demontrate a role - } \\
\text { play in front of the class }\end{array}$ & $\mathrm{X}$ & $\mathrm{X}$ \\
\hline 9. & The students' voluntarily do a role-play demonstration in front of the class & $\mathrm{X}$ & $\mathrm{X}$ \\
\hline 10. & The students spoke loudly and clearly in the front of the classroom & $\mathrm{X}$ & $\mathrm{X}$ \\
\hline 11. & The students speaking practice runs smoothly & $\mathrm{X}$ & \\
\hline 12. & The students speaking test runs smoothly according to the plan & $\mathrm{X}$ & \\
\hline
\end{tabular}

X: Majority

Unlike cycle one, the results show the trends are now switching to the "Yes" side. This means there has been a significant improvement in students' participation and enthusiasm towards tyhe classroom interactions. This happened not only during the preparation for the test in meeting one but especially during the test itself in the second meeting. It is evident that the students' anxiety towards English lesson has been momentarily decreased and hopefully will continue to future English classes after the classroom-action-research is terminated. In the conversation between the doctor (the researcher playing role of an Australian doctor) and the students when playing role as 'interpreter' to a sick relative, hardly anyone bothered to reply to the doctor questions. They replied loudly and confidently enough showing a more natural conversation between the two role players. The current trends in class activeness resulted in positive gain in their speaking scores as shown in the following table.

\section{Evaluating:-}

The great impression by the researcher on the advantage of the oral exercises (here the speaking test) was found in parallel with the scores of the collaborator. The significant increase of the students' scores is indicative of the 
effectiveness of the role-play which is made creative either through guided conversation or free-style conversation. In another side of the classroom, the collaborator, seeing how the class activity is convidence-boosting and motivating, looked as happy as his students were. He admitted that his students have changed a lot as he can see how his students activeness can cover a lot of ground. He quickly grabbed his papers of intruments rushed to take his position and ready to score the students' performance. The results of his scoring is presented in the following table.

Table 5:- Scores of Students' Speaking Test in Cycle 2

\begin{tabular}{|c|c|c|c|c|c|c|c|c|}
\hline \multirow[t]{2}{*}{ No } & Grammar & Vocabulary & Pron & Fluensy & $\begin{array}{l}\text { Team } \\
\text { Work }\end{array}$ & $\begin{array}{l}\text { Self- } \\
\text { Esteem }\end{array}$ & $\begin{array}{l}\text { Total } \\
\text { Score }\end{array}$ & Average \\
\hline & 1 & 2 & 3 & 4 & 5 & 6 & 7 & 8 \\
\hline 1 & 73 & 90 & 82 & 84 & 90 & 90 & 509 & 84.83 \\
\hline 2 & 75 & 90 & 81 & 86 & 89 & 90 & 511 & 85.16 \\
\hline 3 & 77 & 90 & 81 & 82 & 86 & 86 & 502 & 83.66 \\
\hline 4 & 77 & 90 & 84 & 84 & 86 & 86 & 507 & 84.5 \\
\hline 5 & 72 & 79 & 81 & 80 & 88 & 81 & 481 & 80.16 \\
\hline 6 & 65 & 84 & 82 & 82 & 81 & 89 & 483 & 80.5 \\
\hline 7 & 75 & 79 & 78 & 79 & 79 & 87 & 477 & 79.5 \\
\hline 8 & 75 & 79 & 82 & 73 & 83 & 74 & 466 & 77.66 \\
\hline 9 & 82 & 81 & 82 & 63 & 63 & 73 & 444 & 74 \\
\hline 10 & 75 & 84 & 81 & 73 & 67 & 73 & 453 & 75.5 \\
\hline 11 & 69 & 79 & 68 & 68 & 78 & 67 & 429 & 71.5 \\
\hline 12 & 66 & 63 & 67 & 63 & 63 & 67 & 389 & 64.83 \\
\hline 13 & 68 & 67 & 61 & 61 & 66 & 67 & 390 & 65 \\
\hline 14 & 69 & 63 & 63 & 63 & 63 & 65 & 386 & 64.33 \\
\hline 15 & 70 & 70 & 73 & 63 & 62 & 60 & 398 & 66.33 \\
\hline 16 & 67 & 67 & 64 & 64 & 67 & 65 & 394 & 65.66 \\
\hline 17 & 67 & 66 & 73 & 61 & 63 & 65 & 395 & 65.33 \\
\hline 18 & 73 & 75 & 79 & 72 & 61 & 63 & 423 & 70.5 \\
\hline 19 & 65 & 60 & 61 & 63 & 61 & 61 & 371 & 61.33 \\
\hline 20 & 70 & 63 & 63 & 61 & 60 & 61 & 378 & 63 \\
\hline 21 & 66 & 65 & 67 & 65 & 62 & 61 & 386 & 64.33 \\
\hline 22 & 65 & 66 & 65 & 62 & 64 & 63 & 385 & 64.16 \\
\hline 23 & 66 & 71 & 63 & 62 & 61 & 61 & 384 & 64 \\
\hline 24 & 73 & 73 & 74 & 73 & 75 & 75 & 443 & 73.83 \\
\hline 25 & 72 & 61 & 61 & 71 & 63 & 62 & 390 & 65 \\
\hline 26 & 79 & 71 & 81 & 74 & 73 & 73 & 451 & 75.16 \\
\hline 27 & 66 & 76 & 83 & 73 & 75 & 84 & 457 & 76.16 \\
\hline 28 & 65 & 69 & 75 & 72 & 81 & 81 & 443 & 73.83 \\
\hline 29 & 63 & 63 & 62 & 63 & 64 & 63 & 378 & 63 \\
\hline 30 & 70 & 71 & 73 & 75 & 75 & 75 & 439 & 73.16 \\
\hline 31 & 63 & 61 & 63 & 63 & 61 & 65 & 376 & 62.66 \\
\hline 32 & 71 & 73 & 73 & 76 & 77 & 73 & 443 & 73.83 \\
\hline Total & 2249 & 2339 & 2330 & 2254 & 2287 & 2306 & & 2292.4 \\
\hline Average & 70.28 & 73.09 & 72.81 & 70.43 & 71.48 & 72.06 & & 71.63 \\
\hline
\end{tabular}

\section{Reflecting:-}

The increase of mean scores from 56.20 in pretest, 67.82 in cycle one, and 71.63 in cycle two, is obviously important to prove the researcher's assumption that if learners are taught by the teacher by using role-play, they will enjoy their class and subsequently will trigger their motivation to learn English.

As to readiness and attention, it is pointed out that the students did have great enthusiasm for the new classroom interaction as demonstrated by the researcher during treatment of actions in meeting-one class. It is well understood because naturally each of the students wanted to perform best in the final speaking test which they knew would end the research activity. They students seemed to have forgoten already the negative reaction they used to show 
towards the English language. One phenomenon pointed out by the teacher collaborator is that the potential of certain behavior of some able students had given a positive affect to those who are less able. There was evidence that in the first class meeting, the students enthusiastically participated in practicing how to develop their conversation about taking a sick relative to a doctor. Some able students had deliberately chosen a partner from those who are less able to practice together.

\section{Discussion:-}

In this section the researcher would like to express his interpretations and comments in regards to the answers to the research questions indicated by data. The data of mean scores of pretest and the post test fo cycle one and cycle two has yielded useful information about the effectiveness of the role-play teaching strategy. Based on the data (see Table 6) it is revealed that the students speaking ability improved steadily through cycle to cycle and if compared with the pretest result it is evident that the students had obviously made big progress within the two weeks of treatments in this study.

In terms of grammar, at the beginning the majority of learners have a very limited knowledge of grammar (Mean: 56.31). For them grammar is a set of complicated rules and full of conceptions. Despite many grammar books provided by the school, teachers do nothing to demystify grammar. Realizing about this fact the researcher during the treatment process has fruitfully dealt with grammar by encouraging learners to look for patterns when they substituted certain parts of the dialog. Once a pattern has been noted, the researcher encouraged them to generate new language from it (Mean: 70.28).

One of the greatest barrier in learning how to speak English is dealt with vocabulary. Most English learners believe that the only reason they cannot speak English is the lack of vocabulary. The claim is absolutely wrong. The number of vocabulary which we use in our daily conversation either interactional or transactional is, in fact, limited. Teacher could ask his or her students to practice with a few common words but can generate much language depending on the given situation. This has been proved from the research that the learners' prior knowledge vocabulary about illness was limited (Mean: 56.20) but has increased dramatically in cycle three (Mean; 73.9) through scatfolding techniques of vocabulary extension.

Pronunciation has become one of the aspects to be evaluated in speaking test since it is believed that poor pronunciation of any English words may jeopardize process of getting meaning. Realizing its importance, the researcher, in every dialog practice, always helped learners become more aware of the typical pronunciation problems that Tetun speakers may have when speaking English. Certain difficult sounds which are not found in learners' first languages were isolated and drilled accordingly. Besides drilling difficult pronunciation of certain words, pointing out wrongly-stressed syllables is also important because any wrong syllabic stress can lead to misunderstanding. In this case a contrastive analysis technique between first and second language sounds is found usefull.

Table 6:- Comparison of Mean Scores of Components

\begin{tabular}{|l|l|l|l|}
\hline Speaking Components & Pretest & Post Test Cycle One & Post Test Cycle Two \\
\hline Grammar & 53.75 & 63.40 & 70.28 \\
\hline Vocabulary & 58.25 & 69 & 73.9 \\
\hline Pronunciation & 58.12 & 68.90 & 72.81 \\
\hline Fluency & 54.90 & 66.25 & 70.43 \\
\hline Team Work & 56.06 & 69.34 & 71.48 \\
\hline Self-Esteem & 56.31 & 68.12 & 72.06 \\
\hline Average & 56.20 & 67.82 & 71.63 \\
\hline
\end{tabular}

Regarding the non-linguistic expects namely teamwork, fluency, and self-steem some of the actions have contributed significantly to the boost of them. The student's team-work, for example, has become more solid as well as more mutual relient as the pairs began to work hard in preparing themselves for performance before the class either during the practice session or especially during the speaking test. Each member in the team began to realize that the success of his or her role in the play would determine the success of the team. The efforts attempted by students first in memorizing the dialog, then experimenting with dialog extention obviously will help them perform better in terms of fluency. This in turn will give positive affect towards their self-esteem. To summarize, the six 
components of speaking skill have been undoubledly demonstrated a cause-and-effect mechanism to one another component. The following is the comparison of treatment action of cycle one and cycle two which may have contributed to the improvement of students' speaking skills.

Table 7:- Comparison of Action of Two Cycles

\begin{tabular}{|c|c|c|c|}
\hline \multirow[t]{2}{*}{ No } & Cycle 1 & \multirow[t]{2}{*}{ No } & Cycle 2 \\
\hline & Action & & Action \\
\hline 1. & Building schemata of dialog context & 1. & $\begin{array}{l}\text { Building schemata through extenssion of } \\
\text { context. }\end{array}$ \\
\hline 2. & Preteaching new vocabulary & 2. & $\begin{array}{l}\text { Pre-teaching new vocabulary with } \\
\text { examples. }\end{array}$ \\
\hline 3. & Drilling difficult sounds and word pronunciation & 3. & $\begin{array}{l}\text { Drilling difficult sounds with contrastive } \\
\text { analysis technique }\end{array}$ \\
\hline 4. & $\begin{array}{l}\text { Performing role play by reciting dialog before } \\
\text { the class by pairs of students }\end{array}$ & 4. & $\begin{array}{l}\text { Performing role-play through guided } \\
\text { substitution towards free speaking. }\end{array}$ \\
\hline 5. & $\begin{array}{l}\text { Encouraging and motivating students } \\
\text { continuously. } \\
\text { After the treatment the results show less } \\
\text { enthusiasm of students in class participation and } \\
\text { the mean score of speaking test is } 67.82 \text {. }\end{array}$ & 5 . & $\begin{array}{l}\text { Continuing motivating students through } \\
\text { verbal and non-verbal reinforcement. } \\
\text { The results show that the students' } \\
\text { participation in doing the English class } \\
\text { increased dramatically with full enthusiam } \\
\text { and this has contributed to the increase of } \\
\text { their mean score of speaking test which is } \\
71.63 \text {. }\end{array}$ \\
\hline
\end{tabular}

Within this basic information, it has now become evident to us that learners have had abundant benefits of a good implementation of the role-play teaching strategy. In role playing the learners may express feeling and attitudes, become motivated and creative, develop their social skill and be provided with opportunity to feel the situation rather than intellectualize it.

\section{Conclusion:-}

Upon the completion of the classroom action research some advantages as conclusions are noted:

- that in role playing learners get a chance to express their feelngs and attitudes through creative activity provided by the teacher.

- that the method provides opportunity for learners to feel the new situation given by the teacher rather than merely intellectualize about it.

- $\quad$ that the method make learners become motivated and enthusiastic again in learning English. (The learners' lack of motivation and enthussiasm has been a concern of the English teachers of the school so far).

- that because of role-play learners are being prepared for actual situation to be faced. (This is proved by the fact that there was no doubt of learners' readiness for the speaking test in cycle two treatment).

- that the method leads towards the fact that learner and teacher are partners in learning where the teacher is the language-learning 'expert' and the learner the 'expert' on him or herself.

Finally it is important to realize that no matter how principled and systematic the method may be, it is a gradual process and the teacher should not expect instan

\section{Bibliography:-}

1. Agib, Zainal. 2009. Penelitian Tindakan Kelas. untuk : Guru. CV. Yrama Widya, Bandung.

2. Arikunto, Suharsimi, dkk. 2007. Penelitian Tindakan Kelas. Jakarta: Bumi Aksara.

3. Bailey, K., M.(2005). Practical English language teaching speaking. New York: Mc Graw- Hill.

4. Brown, H. (2001). Characteristic of successful speaking activities. New York: Cambridge University press.

5. Burns, A. (2003). Collaborative action research for English language teacher. London: Cambridge Language Teaching Library.

6. Constituant of RDTL (2002). Constituição da Republica De Democratica de Timor Leste Dili: Parliament.

7. De Vaus, D.A. (2001).Research Design in Social Research.London, United Kingdom: SAGE Publications Ltd.

8. Fromkin, Rodman, Hyams, Collins and Amberber (2005; p; 156), An Introduction toLanguage; Fith Edition. 
9. Gillis, G. (2013). The Importance of Speaking Skills. Retrieved March 18, 2017, from

10. http://www.geraldgillis.com/importance-speaking-skills/

11. Graddol, D. (1997). The future of English; A guide to forecasting the population of the English in the 21th century. New York: University Press.

12. Gunther, N., (1982). The Art of Effective Speaking.Adelaide: Reed.

13. Islam, P. and Islam, T. , (2012). The effectiveness of role play in enhancing speaking.

14. Retrieved March 18, 2017, from www.banglajol.info/index.php/SJE/arctile /view/14475.

15. Kolo, C. (2017). English is as a Language Franca. Kupang: Universitas Nusa Cendana.

16. Kumar, P. (2012). What is the role of play in child development? Retrieved March 18, 2017, fromhttp://www.preservearticles.com/2012022323569/what-is-the-role-of-play-in-child-development.html

17. Harmer, J, (1998). The practice of English language teaching( $3 \mathrm{th}^{\mathrm{Ed}}$ ). New York: Longman Lewin, K. (2017). Action Research $\quad$ Spiral. $\quad$ Retrieved $\quad$ March $18, \quad$ 2017, from https:/www.bing.com/images/search?q=spiral+of+action+research\&qpvt=spiral+of+action+research+\&qpvt=s piral+of+action+research+\&qpvt=spiral+of+action+research+\&FORM=IGRE

18. Love Role play (n.d.).Kinds and types of roleplays. Retrieved March 19, 2017, from http://loveroleplay.wikia.com/wiki/Kinds_and_Types_of_Roleplays?oldid=10748

19. MacKay, A.L. (2003).Teaching English as a Lingua França. Oxford: Oxford University Press.

20. McNiff, J. (1994). Action Research: Principles and Practice. Basingstoke, United Kingdom: Macmillan Publishers.

21. Nuhan, D. (2003). Practical English language teaching.New York: Mc Graw Hill.

22. O'Brien, R. (1998). An Overview of the Methodological Approach of Action Research .Retrieved on May 26, 2014, from http://www.web.ca/robrien/papers/arfinal.html

23. Phillips, B., D. (1993).Role playing games in the English as a foreigner language classroom. Retrieved on 18 March, 2017, from www.interactivedramas.info.

24. Sinclair, J. (1980). Advance learner's dictionary. London: Haper Collins Publishers.

25. Susanti, A., D., H. (2007). Using role play in teaching speaking. Jakarta: State Islamic University.( Susanti (2007). Using role play in teaching speaking skill)

26. Thomas, R., M. (2003).Blending Qualitative \& Qualitative Research Methods. California: Corwin Press.

27. Thomson,M.(2006). Collins Australia Dictionary. Melbourne: Collins Gem

28. Thornbury, S.(2005). How to teach speaking. London: Pearson Education Limited. 